Volume 8, No.3, May - June 2019

International Journal of Advanced Trends in Computer Science and Engineering

Available Online at http://www.warse.org/IJATCSE/static/pdf/file/ijatcse30832019.pdf

https://doi.org/10.30534/ijatcse/2019/30832019

\title{
Development of an Optimized Greenhouse Automation System
}

\author{
Sven Erikson L. Cheng, Lindsey Gjames B. Lim, Jay Herson C. Ramos \\ De La Salle University, Manila \\ 2401 Taft Ave., Malate, Manila 1004, Philippines \\ sven_cheng@dlsu.edu.ph,
}

\begin{abstract}
ZIGBEE is widely used in applications that involved in monitoring and communicating functions. ZIGBEE technology is used in monitoring and controlling the growth of a potato plant inside a greenhouse system. It communicates wirelessly to sensor circuits to maintain the overall aspect needed for a suitable environment in growing potatoes. Light, Water, and Temperature are some of the factors being controlled. The purpose of this thesis is to look into the possibility of using ZIGBEE in Greenhouse application.
\end{abstract}

Key Words: Database, Greenhouse, Sensors, Zigbee Technology, Optimization, Rough Set Theory

\section{INTRODUCTION}

Philippine markets are seeing heavy competition from foreign crops, particularly in the high yield area. Cool weather crops are mostly grown on mountainous areas such as Baguio where cool climate exists. Certain crops such as potatoes, lettuce, avocados and breeds of flowers require different conditions for high-quality yield. Weather, soil, humidity, light intensity and $\mathrm{PH}$ level are some of the factors that are controlled within a greenhouse [1].

The Department of Agriculture in the Philippines is planning to fund several greenhouse projects in the provinces more specifically Eastern Visayas due to the high-quality produce that are flooding the market. Studies have shown that the plants grown in a controlled environment give higher and better yields. Crops and flowers may also be grown all year round because greenhouses control the climate and the natural environment within it. Philippines exportation of goods will improve and be competent by developing and automating greenhouses in the country [2].

A potato plant will undergo this study to test the effectiveness of the system compared to normally grown potatoes outside [3]. The Factors inside the greenhouse are pre-programmed based on the requirements of the plant. Potatoes are considered a "cool weather" crop and the challenge is meeting the different requirements of the potato during its different stages of development. The roof controller will shift the translucent material that regulates the temperature [4]. The shade alone is not sufficient to regulate the internal temperature; therefore, water spraying and ventilation system will also be incorporated. The temperature sensor will deliver up to date information on the condition of the greenhouse. The user may override the system anytime even from a remote distance.

The system will include not only real-time data gathering but also control of the entire operation within the greenhouse. Wireless communication between devices will be implemented using ZIGBEE technology to provide reliable data information [5]. A user-friendly interface will monitor and control the overall aspects inside the greenhouse for ease and convenience.

\section{SYSTEM COMPONENTS}

\subsection{ZIGBEE}

Zigbee is a personal area network (PAN) that is designed specifically to substitute the proliferation of individual remote controls [6]. It was created to provide and satisfy the market's needs of a cost-effective, standard-based network which supports low power consumption and data rates, along with stable security and reliability. Mainly, Zigbee is the only standards-based technology that addresses the needs for most remote monitoring/control and sensory network allocations [7]. It is basically designed to provide highly efficient connectivity between small packet devices and targeted at radiofrequency (RF) applications which require a low data rate along with lengthy battery life and secure networking. The transmission rate of data varies from 20 to 250 kilobits/second with a maximum range of operation up to 250 feet or approximately 76 meters. The project will utilize a pair of Zigbee modules as its means of communication, one will be the transmitter and the other would be the receiver. Instead of RFID [8], Zigbee would be used. 


\subsection{Temperature Sensor}

For the Temperature monitoring system, the LM35 was chosen as the temperature sensor [9]. The group's temperature monitoring will also include an easy to read LCD display for easy tracking. The LM35 is comparatively more accurate and linear in terms of sense. The parameter of the LM35 is set in Celsius format. The output voltage is varied by $10 \mathrm{mV}$ per degree Celcius. There is a discrepancy of \pm 0.4 degrees. It needs 2 minutes to reach target output voltage, and 4 minutes to attain equilibrium [10].

\subsection{Soil Moisture Sensor}

The soil moisture sensor is based on a capacitive circuit that measures the conductance of the soil with the use of 2 metal conducting probes. The circuit is composed with a Quad Op-amp TC084CN that serves as an oscillator, differential amplifier, and rectifier. For further testing, the Logic Scoring of Preference can be used [11]. A $1 \mathrm{KHz}$ square wave frequency is produced by the oscillator which will be canceled or attenuated by the differential amplifier depending on the input frequency signal from the probe and oscillator [12]. The rectifier is responsible for converting the output signal obtained from the differential amplifier into its equivalent DC value. If the capacitance value obtained is high, then the conductivity level of the soil moisture content is low and vice versa. The moisture content of the soil will then vary depending on the conductivity level from the 2 metal probes. USB can also be used to transfer data and information [13].

\subsection{IRC Slimboard with Z8F6421 Flash Microcontroller}

IRC Slimboard is an integrated development module, which employs the Z8F6421 Flash microcontroller and Zilog's advanced Z8 microprocessor. The primary advantage of microcontrollers of this type is its on-circuit reprogrammable and debugging capabilities. Thus separate tools such as an IC programmer and corresponding development board for a specific model such as the ones being manufactured by Microchip (e.g. PIC18F4550) are eliminated [14]. However, a common problem that is usually encountered is the spike of the microprocessor. One way to improve this is to use a Spatial Algorithm and Neural Network System [15,16].

The versatility for its use in embedded applications is supported by the availability of 60 pins that can function either as I/O ports or ADC converters, and the essential peripherals such as timers and UART [17]. Furthermore, another advantage of the said microcontroller type is the capacity to program its $4 \mathrm{~kb}$ RAM using C language [18].

\subsection{Greenhouse prototype}

Greenhouses are normally constructed with four walls and a triangular roof. Sensors were added to measure parameters [19]. All of which are made of glass and other materials that insulate the heat and control the climate and temperature inside the structure. Our greenhouse is built to simulate cold climate conditions in an urban setting. Fiber glasses are still used on 2 sides of the greenhouse with adjacent wooden walls. The roof is made of common glass material, which can be readily removed in order to provide good accessibility to the plants being cultivated and monitored (figure 1).

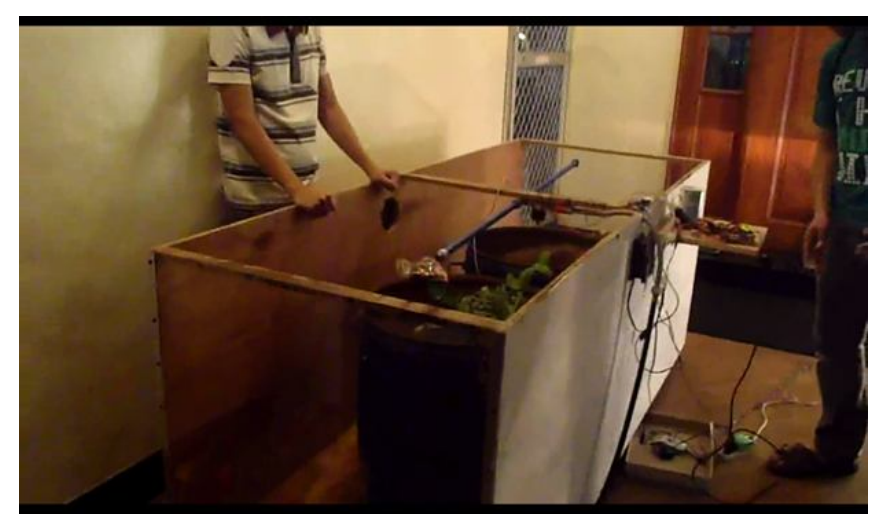

Figure 1: Greenhouse Prototype

\subsection{Microsoft Visual Basic}

There are several programming languages and compilers available in developing a program or graphic user interfaces like C++ and Visual Basic which are one of the popular ones. Microsoft Visual Basic is used as the programming tool being relatively easier to learn and simpler to use. Basically, it is athird-generation eventdriven programming language and integrated development environment (IDE). This is primarily for developers to have an easy way in creating client applications with drag and draw features that assign codes to add meaningful events on a Windows program. Simply put as the program is drawn, the code is written at the same time. It enables rapid application development (RAD) of graphical user interface (GUI) programs and provides unique software architecture with Windows.

\section{DESIGN CONSIDERATIONS}

\subsection{System Set - up}

As shown in Figure 2, the system's core is the Zilog microcontroller and the Zigbee coordinator. The microcontroller accepts input from the soil moisture sensor's capacitive comparator and the temperature sensor's serial input. The microcontroller's output is directed to the LCD display, Tunnel Ventilation and water solenoid sprinkler. The Zilog MCU also outputs to the data logger program using the ZigBee coordinator. The 
ZigBee slave then receives the transmission then the data logger saves the data. The process is repeated using different sampling times for each input. Testing the Zigbee System requires Neural Network software testing [20].

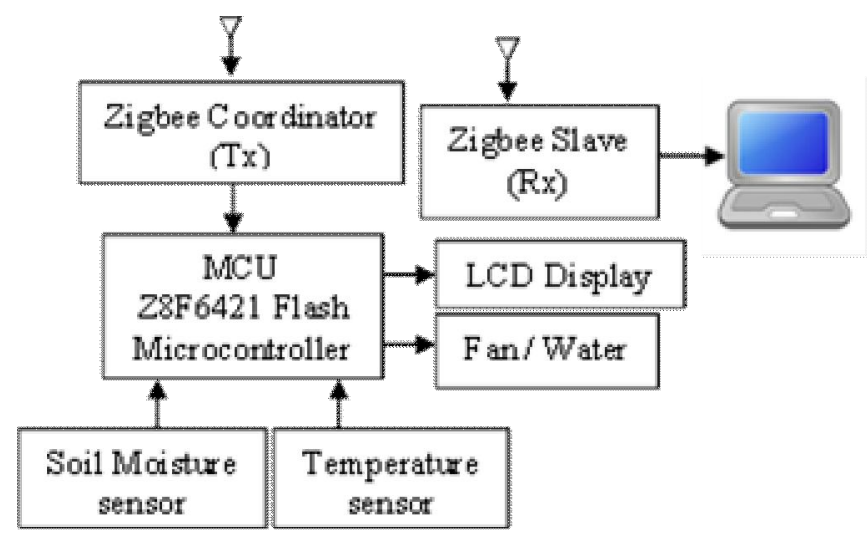

Figure 2: System Block Diagram

\subsection{Light Sensor}

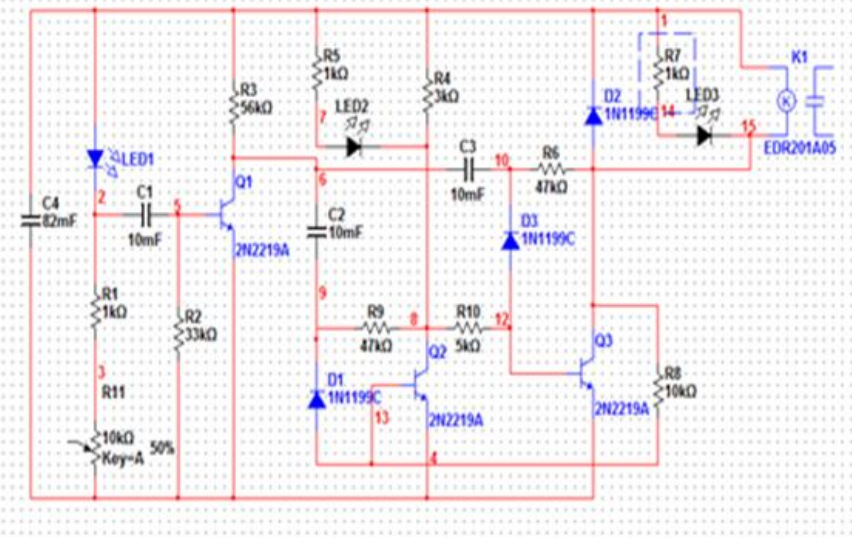

Figure 3: Schematic Diagram of Light Sensor

This circuit uses an LDR which opposes current from flowing to $\mathrm{C} 1$. Therefore it limits the voltage across $\mathrm{C} 1$ to about $0.3 \mathrm{~V}$. When the light strikes LDR its resistance drops allowing current to flow to the bases of Q1 bringing it to conduction. Q2 and Q3 are like flip flops and they conduct alternately. At the juncture the relay will switch when the light is enough [21].

\subsection{Dark Sensor}

Automatic dark detector senses darkness. As the light level decreases and LDR meets the maximum threshold resistance, the circuit automatically switches on the Motor.

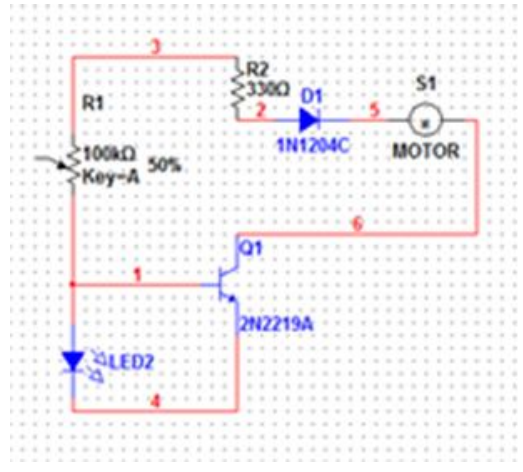

Figure 4: Schematic Diagram of Dark Sensor

\subsection{Solenoid Water Valve}

A solenoid water valve is used to control our water cooling system. The Manufacturer was Hydroelectric. We chose this particular valve due to its operating voltage of 12 volts [22]. Most of the devices used in the system require the same voltage level therefore a common source is being utilized to cut back on expenses. The solenoid valve can be configured to output .25 -17 liters per minute. The pressure that we require is also met by the solenoid valve.

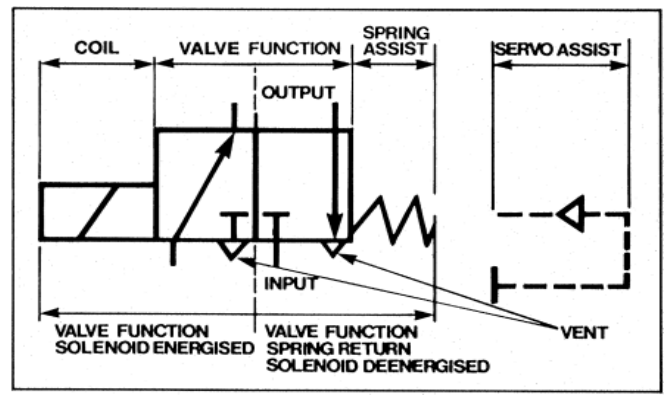

Figure 5: Solenoid Valve Functions

\subsection{Roof Control System}

A roof sensing circuit will maintain the amount of light needed in the greenhouse system to regulate the air temperature inside. The Light/Dark sensor will control the motor and the limit switch of the roof. If there is too much light, the roof will be automatically be covered with a tinted sunscreen film and will uncover it respectively when it is dark. 


\subsection{Process Flow of Microcontroller Program}

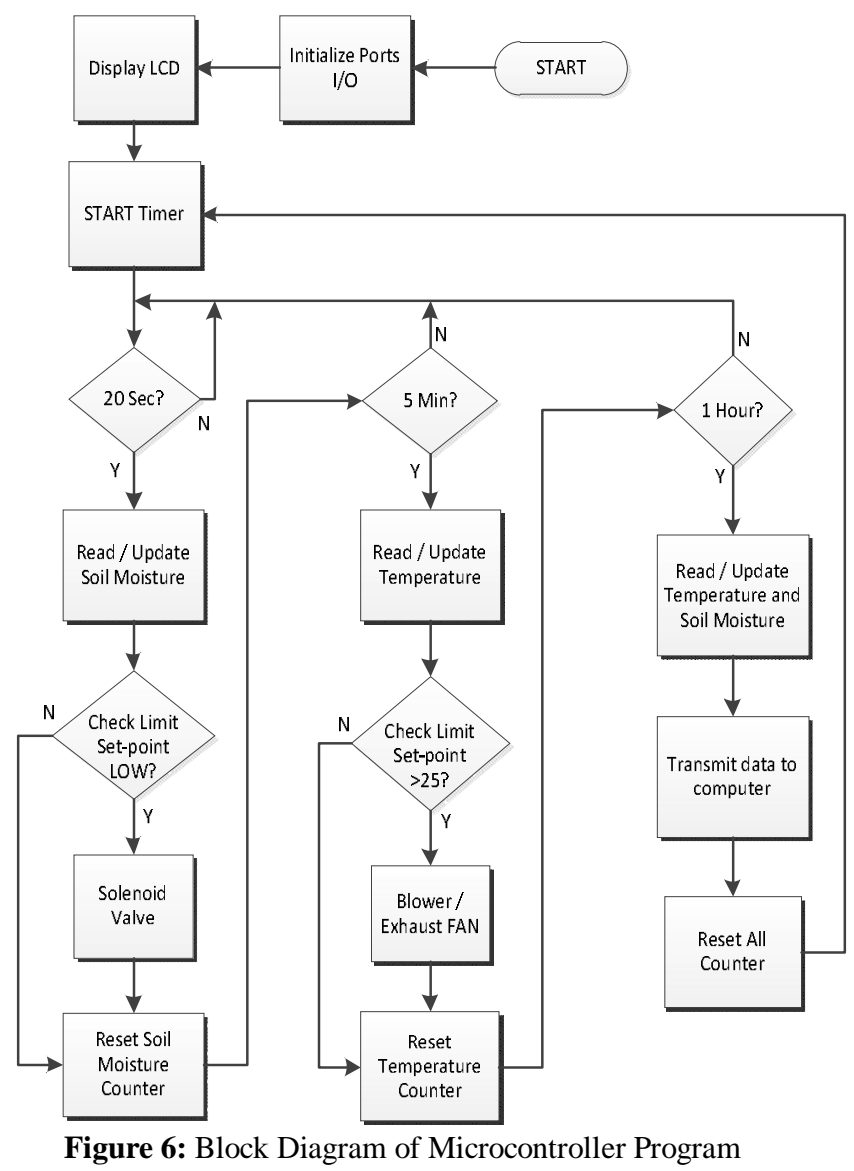

\subsection{Rough Set Theory Test}

The basic industrial electric fan will be used as the entrance of our cross flow tunnel ventilation. The output of the System will be inputted in the database. A Rough Set Theory Algorithm will be used to optimize its result $[23,24]$. The Rough Set Theory are based on the Works of Palwak [25].

The base of the fan will be disassembled then mounted on a wooden housing. The fan will also be positioned facing the plant to maximize the airflow. The exhaust fan used will be a water proof exhaust fan. This exhaust fan will be positioned on the opposite side of the greenhouse. The database of the system will be in the form on an Information System $\mathrm{S}=(\mathrm{U}, \mathrm{A})$. Information System [26, 27].

\section{DATA AND RESULTS}

\subsection{Temperature Sensor Test}

The data acquired from our testing procedures reveal that the temperature sensor used by the group for the thesis prototype is accurate especially when measuring ambient temperatures of a particular environment. Thus it displayed enough sensitivity to quantify the changes on the temperature within the greenhouse prototype while it is being managed by the corresponding control system [28]. Temperature sensor test details is shown in table 1.

Table 1: Temperature Sensor Test

\begin{tabular}{lll}
\hline \hline $\begin{array}{l}\text { Hg } \\
\text { Thermometer } \\
\text { Reading }\left({ }^{\circ} \mathrm{C}\right)\end{array}$ & $\begin{array}{l}\text { Temperature } \\
\text { Sensor } \\
\text { Reading }\left({ }^{\circ} \mathrm{C}\right)\end{array}$ & $\begin{array}{l}\text { Percent } \\
\text { Difference }\end{array}$ \\
\hline 31 & $\mathbf{2 8 . 1 2}$ & $\mathbf{9 . 7 \%}$ \\
32 & $\mathbf{2 9 . 3 2}$ & $\mathbf{8 . 7 \%}$ \\
32 & $\mathbf{2 8 . 1 3}$ & $\mathbf{1 2 . 8 7 \%}$ \\
32 & $\mathbf{2 9 . 1 7}$ & $9.25 \%$ \\
30 & $\mathbf{2 7 . 7}$ & $\mathbf{7 . 9 7 \%}$ \\
\hline
\end{tabular}

\subsection{Zigbee Distance Test}

The Zigbee distance test confirms that the Zigbee modules are more than enough to satisfy the size requirements of a Greenhouse. Greenhouses in the Philippines are standardly 10 feet by 40 feet, therefore the ZigBee is more than sufficient to cover the entire greenhouse [29]. ZIGBEE distance test details is shown in table 2.

Table 2: ZIGBEE Distance Test

\begin{tabular}{ll}
\hline \hline Distance (ft) & $\begin{array}{l}\text { Signal Received } \\
\text { (Y/N) }\end{array}$ \\
\hline 10 & Yes \\
15 & Yes \\
20 & Yes \\
25 & Yes \\
30 & Yes \\
With physical isolation (concrete & Yes \\
and door) & \\
35 & Yes \\
40 & Yes \\
40 feet With Physical Isolation & No signal \\
(concrete and doors) & \\
50 & Yes \\
60 & No signal \\
\hline
\end{tabular}

\subsection{Soil Moisture Sensor Test}

The Soil moisture sensor was very sensitive in detecting highly saturated and dehydrated soil. In conditions where the soil moisture was adequate, the output flashed both High and Mid LED. Based on the Zilog programming scheme we designed the water solenoid valve to open only if the soil moisture module outputted a Low output 
(Red LED). The output was immediate and very accurate as to the situation of the soil. Table 3 shows soil moisture sensor test.

Table 3: Soil Moisture Sensor Test

\begin{tabular}{lll}
\hline \hline Soil Moisture & $\begin{array}{l}\text { Soil Moisture } \\
\text { Reading }\end{array}$ & Voltage Level \\
\hline Very Dry Soil & Low & $\geq 0.25 \mathrm{~V}$ \\
Newly Watered Soil & High & $\leq 1.0 \mathrm{~V}$ \\
$\begin{array}{l}\text { Water Saturated } \\
\text { Soil High }\end{array}$ & & $\leq 1.0 \mathrm{~V}$ \\
$\begin{array}{l}\text { Normal Water } \\
\text { content }\end{array}$ & Mid/ Low & $0.26 \mathrm{~V}-0.99 \mathrm{~V}$ \\
\hline
\end{tabular}

\subsection{Potato Growth}

The group's potato tubers were planted and after 15days the sprouting stage was complete and we observed quick growth of stem and initial buds. This is within the expected sprouting period of 2 weeks. The 15 days should not be counted as growth period because this was merely the appearance of initial roots stem and buds. The group, therefore, had 81 days to cultivate the plant. Stage 2 of the growth stage began around August 26-31. Stage 2 was entered by the greenhouse plant after 33 days from planting. This is within the expected outcome, because stage 2 takes about 30-70 days. The 2nd to 3rd stage transition of growth took approximately 12 days again this is within the expected result.

Table 4: Potato Growth Stages

\begin{tabular}{|c|c|c|c|}
\hline & $\begin{array}{l}\text { Philippine } \\
\text { Recommends }\end{array}$ & $\begin{array}{l}\text { Benguet State } \\
\text { University }\end{array}$ & $\begin{array}{l}\text { Thesis } \\
\text { group }\end{array}$ \\
\hline $\begin{array}{l}\text { Planting } \\
\text { stage } \\
\text { (tuber } \\
\text { seeds) }\end{array}$ & $\begin{array}{l}\text { Pre-sprouted } \\
\text { tubers } \quad 2-3 \mathrm{~cm} \\
\text { long }\end{array}$ & $\begin{array}{l}\text { Pre-sprouted } \\
\text { tubers } \quad 1-3 \mathrm{~cm} \\
\text { long }\end{array}$ & $\begin{array}{l}\text { Fully } \\
\text { grown } \\
\text { potatoes } \\
\text { already } \\
\text { sprouted } \\
8-14 \mathrm{~cm}\end{array}$ \\
\hline Stage 1 & $\begin{array}{l}\text { Approximately } \\
2 \text { weeks }\end{array}$ & $\begin{array}{l}\text { Approximately } \\
2 \text { weeks }\end{array}$ & 15 days \\
\hline Stage 2 & 2-4weeks & 2-3 weeks & 18 days \\
\hline Stage 3 & $\begin{array}{l}\text { Approximately } \\
2 \text { weeks }\end{array}$ & $\begin{array}{l}\text { Approximately } \\
2 \text { weeks }\end{array}$ & 12 days \\
\hline Stage 4 & $\begin{array}{l}\text { Approximately } \\
1 \text { month }\end{array}$ & Up to a month & 36 days \\
\hline Stage 5 & 3-4 months & $\begin{array}{l}\text { Until the plant } \\
\text { dies }\end{array}$ & \\
\hline
\end{tabular}

\subsection{Potato Yield}

As presented in Table 5 below, the automated greenhouse was able to yield 452 grams. This yield is higher than the low elevation yield in areas such as Cabuyao, Laguna \&
UP Los Bańos: Bayog, Los Bańos, Laguna; \& Angat, Bulacan. But the automated greenhouse yield is lower when compared to areas such as Mountain trail and La Trinidad. The maturity period of the greenhouse plant was also in between the maturity of low elevation and high elevation plants. If given more time and if the pest problem were avoided the group's potato plant would have surely yielded more. Also, during rainy seasons the yield of the entire country plummets. Data mining and Optimization Algorithms like the Rough Set Theory can also be used to optimize the data [30,31,32].

Table 5: Data Yield Comparisons

\begin{tabular}{llll}
\hline \hline Location & $\begin{array}{l}\text { Maturity } \\
\text { Period } \\
\text { (days) }\end{array}$ & $\begin{array}{l}\text { Yield } \\
\text { (grams) }\end{array}$ & $\begin{array}{l}\text { Climate } \\
\text { conditions }\end{array}$ \\
\hline $\begin{array}{l}\text { Mountain } \\
\text { trail, Baguio }\end{array}$ & $80-90$ & $539-566$ & $\begin{array}{l}\text { High elevation } \\
\text { (optimal } \\
\text { weather) }\end{array}$ \\
$\begin{array}{l}\text { La Trinidad, } \\
\text { Baguio }\end{array}$ & $80-90$ & $755-809$ & $\begin{array}{l}\text { High elevation } \\
\text { (optimal } \\
\text { weather) }\end{array}$ \\
$\begin{array}{l}\text { UP } \\
\text { Banos }\end{array}$ & 70 & $382-474$ & $\begin{array}{l}\text { Low elevation } \\
\text { (normal } \\
\text { weather) }\end{array}$ \\
$\begin{array}{l}\text { Cabuyao, } \\
\text { Laguna }\end{array}$ & 70 & $382-474$ & $\begin{array}{l}\text { Low elevation } \\
\text { (normal } \\
\text { weather) } \\
\text { Low elevation } \\
\text { (normal } \\
\text { weather) }\end{array}$ \\
$\begin{array}{l}\text { Angat } \\
\text { Bulacan }\end{array}$ & 70 & 369 & \\
$\begin{array}{l}\text { Thesis } \\
\text { Greenhouse }\end{array}$ & 81 & 452 & Controlled \\
\hline
\end{tabular}

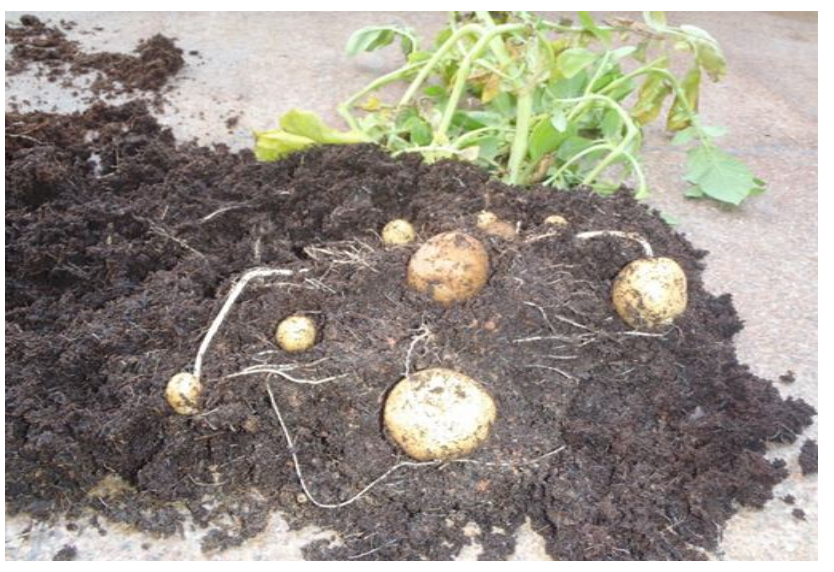

Figure 7: Potato Yield

\section{CONCLUSION}

The Automated Greenhouse System implemented with the Zigbee Standard was able to operate for most parts of the day and night. However, there were many instances where the system had to be restarted. The restart process 
involved merely unplugging the power and restarting the laptop computer. This happened many times during the entire growth process of the potato. The Automated Greenhouse System implemented with the Zigbee Standard was able to keep the potatoes free from nature's wrath such as powerful wind of typhoon and other natural calamities. The searing heat of the sun was also a very important factor, because potatoes cannot survive in too much heat. The temperature inside the automated greenhouse was a few degrees lower compared to the outside temperature. The water evaporation coupled with the tunnel ventilation were effective in lowering the temperature dramatically.

\section{RECOMMENDATIONS}

The researchers would recommend dry ice to be injected into the Greenhouse, enabling the Greenhouse to cool more effectively and start growing crops that require cold temperature such as strawberry. Any future researches that will use this thesis must be more experienced in planting crops. The group was unable to employ techniques in raising crops such as stem cutting, proper spacing, dehulling and many other end techniques. Crops such as iceberg lettuce, strawberries, grapes and other cold weather crops can be planted in the automated greenhouse. These crops are more expensive and will absolutely boost the agricultural output of the Philippines and make life better for the ordinary farmer. The future for high output yield in the Philippines will rely on technology to better serve mankind.

\section{REFERENCES}

[1] A. Go, A. Conag, R. Igdon, A. Toledo and J. Malila, "Potentials of agricultural and agro-industrial crop residues for the displacement of fossil fuels: A Philippine context," Energy Strategy Reviews. Vol. 23, pp. 100-113, 2019. https://doi.org/10.1016/j.esr.2018.12.010

[2] N. Salayo, M. Perez, L. Garces and M. Pido, "Mariculture development and livelihood diversification in the Philippines," Marine Policy. Vol. 36, No.4, pp. 867-881, 2012. https://doi.org/10.1016/j.marpol.2011.12.003

[3] L. Bidondo, N. Almasia, A. Bazzini, R. Colombo, E. Hopp, C. Vasquez-Rovere and A. Godeas, "The overexpression of antifungal genes enhances resistance to rhizoctonia solani in transgenic potato plants without affecting arbuscular mycorrhizal symbiosis," Crop Protection. 2019.

[4] S. Sonnewald, J. Harsselaar, K. Ott, J. Lorenz and U. Sonnewald, "How Potato Plants Take the Heat?," Procedia Environmental Sciences. Vol. 29, p. 97, 2015.

https://doi.org/10.1016/j.proenv.2015.07.178
[5] A. Abane, M. Daoui, S. Bouzefrane and P. Muhlethaler, "NDN-over-ZigBee: A ZigBee support for Named Data Networking," Future Generation Computer Systems. Vol. 93, pp. 792-798, 2019. https://doi.org/10.1016/j.future.2017.09.053

[6] O.P. Bodunde, U.C. Adie, O.M. Ikumapayi, J.O. Akinyoola and A.A. Aderoba, "Architectural design and performance evaluation of a ZigBee technology based adaptive sprinkler irrigation robot," Computers and Electronics in Agriculture. Vol. 160, pp. 168178, 2019. https://doi.org/10.1016/j.compag.2019.03.021

[7] F. Farha and H. Chen, "Mitigating replay attacks with ZigBee solutions," Network Security. Vol. 2018, No. 1, pp. 13-19, 2018. https://doi.org/10.1016/S1353-4858(18)30008-4

[8] A. Africa, S. Bautista, F. Lardizabal, J. Patron, and A. Santos, "Minimizing Passenger Congestion in Train Stations through Radio Frequency Identification (RFID) coupled with Database Monitoring System.” ARPN Journal of Engineering and Applied Sciences. Vol. 12, No. 9, pp. 2863-2869, 2017.

[9] A. Khan, N. Ul Haq, I. Chughtai, A. Shah and K. Sanaullah, "Experimental investigations of the interface between steam and water two phase flows," International Journal of Heat and Mass Transfer. Vol. 73, pp. 521-532, 2014.

https://doi.org/10.1016/j.ijheatmasstransfer.2014.02.035

[10] O. Bamodu, F. Osebor, L. Xia, A. Cheshmehzangi and L. Tang, "Indoor environment monitoring based on humidity conditions using a low-cost sensor network," Energy Procedia. Vol. 145, pp. 464-471, 2018. https://doi.org/10.1016/j.egypro.2018.04.093

[11] A. Africa, "A Logic Scoring of Preference Algorithm using ISO/IEC 25010:2011 for Open Source Web Applications Moodle and Wordpress," ARPN Journal of Engineering and Applied Sciences. Vol. 13, No. 15, pp 4567-4571, 2018.

[12]F. Khateb, T. Kulej, M. Kumngern and C. Psychalinos, "A compact power-efficient $0.5 \mathrm{~V}$ fully differential difference amplifier," AEU International Journal of Electronics and Communications. Vol. 105, pp. 71-77, 2019. https://doi.org/10.1016/j.aeue.2019.04.007

[13] A. Africa, A. Mesina, J. Izon, and B. Quitevis, "Development of a Novel Android Controlled USB File Transfer Hub." Journal of Telecommunication, Electronic and Computer Engineering. Vol. 9, Nos. 2-8, pp. 1-5, 2017.

[14] B.N.Jamadar, S.R.Kumbhar, P.M.Gavane and D.S.Sutrave, "Design and Development of Control System for Three Phase Induction Motor using PIC Microcontroller." IFAC Proceedings Volumes. Vol. 47, No. 1, pp. 807-811, 2014. https://doi.org/10.3182/20140313-3-IN-3024.00072 
[15] P. Loresco and A. Africa, "ECG Print-out Features Extraction Using Spatial-Oriented Image Processing Techniques." Journal of Telecommunication, Electronic and Computer Engineering. Vol. 10, Nos. 1-5, pp. 15-20, 2018.

[16] A. Africa and J. Velasco, "Development of a Urine Strip Analyzer using Artificial Neural Network using an Android Phone." ARPN Journal of Engineering and Applied Sciences. Vol. 12, No. 6, pp. 1706-1712, 2017.

[17] Z. Hu, J. Zhang and X. Luo, "A Novel Design of Efficient Multi-channel UART Controller Based on FPGA." Chinese Journal of Aeronautics. Vol. 20, No. 1, pp. 66-74, 2007. https://doi.org/10.1016/S1000-9361(07)60009-0

[18] M. Rivas and H. Tijero, "Leveraging real-time and multitasking Ada capabilities to small microcontrollers." Journal of Systems Architecture. Vol. 94, pp. 32-41, 2019. https://doi.org/10.1016/j.sysarc.2019.02.015

[19] A. Africa, J. Aguilar, C. Lim Jr, P. Pacheco and S. Rodrin, "Automated Aquaculture System that Regulates Ph, Temperature and Ammonia." 9th International Conference on Humanoid, Nanotechnology, Information Technology, Communication and Control, Environment, and Management (HNICEM). 2017. https://doi.org/10.1109/HNICEM.2017.8269494

[20] S. Brucal, A. Africa and E. Dadios, "Female Voice Recognition using Artificial Neural Networks and MATLAB Voicebox Toolbox." Journal of Telecommunication, Electronic and Computer Engineering. Vol. 10, Nos. 1-4, pp. 133-138, 2018.

[21] H. Wang, D. Li, C. Wu and X. Yu, "Depth perception of moving objects viaing structured light sensor with unstructured grid." Results in Physics. Vol. 13, 2019. https://doi.org/10.1016/j.rinp.2019.102163

[22] M. Ilbas and S. Karyeyen, "An experimental and numerical study on turbulent combustion of hydrogen-rich coal gases in a generated nonpremixed burner." Fuel. Vol. 194, pp. 274-290, 2017. https://doi.org/10.1016/j.fuel.2017.01.016

[23] A. Africa and M. Cabatuan, "A Rough Set Based Data Model for Breast Cancer Mammographic Mass Diagnostics." International Journal of Biomedical Engineering and Technology. Vol. 18, No. 4, pp.359369, 2015. https://doi.org/10.1504/IJBET.2015.071010

[24] A. Africa, “A Rough Set Based Solar Powered Flood Water Purification System with a Fuzzy Logic Model." ARPN Journal of Engineering and Applied Sciences. Vol. 12, No. 3, pp.638-647, 2017.

[25] Z. Palwak, "Rough Sets." International Journal of Computer and Information Science. Vol. 11, pp. 341356. 1982.https://doi.org/10.1007/BF01001956

[26] A. Africa, "A Mathematical Fuzzy Logic Control Systems Model Using Rough Set Theory for Robot
Applications." Journal of Telecommunication, Electronic and Computer Engineering. Vol. 9, No. 28, pp. 7-11, 2017.

[27] A. Africa, "A Rough Set-Based Expert System for diagnosing information system communication networks." International Journal of Information and Communication Technology. Vol. 11, No. 4, pp. 496512, 2017. https://doi.org/10.1504/IJICT.2017.10008315

[28] A. Samal, A. Mohanty, P.K. Ray, S. Mohanty and P.P. Mohanty, "Implementation of digital temperature control system on photovoltaic cell model: An experimental analysis." Optik. Vol. 176, pp. 324-333, 2019. https://doi.org/10.1016/j.ijleo.2018.09.095

[29] J. Stepien, J. Kolodziej and W. Machowski, "Mobile user tracking system with ZigBee." Microprocessors and Microsystems. Vol. 44, pp. 47-55, 2016. https://doi.org/10.1016/j.micpro.2016.02.007

[30] M. Tawarish and K. Satyanarayana, "A Review on Pricing Prediction on Stock Market by Different Techniques in the Field of Data Mining and Genetic Algorithm." International Journal of Advanced Trends in Computer Science and Engineering (IJATCSE). Vol. 8, No. 1, pp. 23-26, 2019.

[31] D. Ahamad, M. Akhtar and S. Hameed, "A Review and Analysis of Big Data and MapReduce." International Journal of Advanced Trends in Computer Science and Engineering (IJATCSE). Vol. 8, No. 1, pp. 1-3, 2019. https://doi.org/10.30534/ijatcse/2019/05812019

[32] A. Africa, "A Rough Set Data Model for Heart Disease diagnostics." ARPN Journal of Engineering and Applied Sciences. Vol. 11, No.15, pp. 93509357, 2016. https://doi.org/10.30534/ijatcse/2019/01812019 